\title{
Cloning of two genes from Bacillus circulans WL-12 which encode 1,3- $\beta$-glucanase activity
}

\author{
Michael J. Fiske, ${ }^{*} \dagger$ Karen L. Tobey-Fincher and Roy L. FuchS \\ Monsanto Company, Biological Sciences Department, 700 Chesterfield Village Parkway, St Louis, Missouri 63198, USA
}

(Received 27 February 1990; revised 25 June 1990; accepted 9 August 1990)

\begin{abstract}
Two genes encoding distinct 1,3- $\beta$-glucanases have been cloned from Bacillus circulans and expressed in Escherichia coli. A cosmid library of $B$. circulans WL-12 DNA was constructed in the broad-host-range cosmid pLAFR1 and screened in $E$. coli for clones which exhibited 1,3- $\beta$-glucanase activity. Two 1,3- $\beta$-glucanase-positive clones were identified which contained genes encoding two independent 1,3- $\beta$-glucanases as shown by biochemical, physical and molecular analyses. The cosmids, designated pMON5401 (27.1 kb insert) and pMON5402 (24.7 kb insert), encoded $68 \mathrm{kDa}$ and $40 \mathrm{kDa}$ 1,3- $\beta$-glucanases, respectively. Both 1,3- $\beta$-glucanases were purified from their respective $E$. coli strains, characterized biochemically, and were shown to exhibit lytic activity against purified yeast cell wall preparations.
\end{abstract}

\section{Introduction}

Knowledge gained over the past decade has made the engineering and expression of foreign genes in plants a practical method to produce plants tolerant to certain classes of insects (Barry, 1986; Barton et al., 1987; Fischhoff et al., 1988; Vaeck et al., 1987), viruses (Abel et al., 1986; Tumer et al., 1987) and herbicides (De Block et al., 1987; Shah et al., 1986). An analogous approach to generate plants tolerant to fungi suffers from our limited knowledge of specific proteins which have significant antifungal activity. To date, no proteins comparable to the Bacillus thuringiensis toxin proteins for insect control have been identified which control fungi. One potential approach for fungal control is to use genes which encode hydrolytic enzymes for specific degradation of fungal cell wall components.

The cell walls of many plant-pathogenic fungi contain $1,3-\beta$-glucans and chitin as essential integral structural components (Kobayashi et al., 1974c; Sietsma \& Wessels, 1979; Skujins et al., 1965). Numerous microorganisms produce and secrete the hydrolytic enzymes $1,3-\beta$-glucanase and chitinase, which have been suggested to function synergistically to degrade the cell walls of these pathogens (Chesters \& Bull, 1963; Horikoshi \& Atsukawa, 1973; Kobayashi et al., 1974c). Plants, likewise, have evolved the ability to induce both $1,3-\beta$ -

† Present address: Genencor International, 1700 Lexington Avenue, Rochester, New York 14652-3605, USA. glucanase and chitinase activities in response to fungal infection (Bell, 1981; Nichols et al., 1980). This suggests that these enzymes may be involved in disease protection (Nitzsche, 1983). It has been reported that although neither the 1,3- $\beta$-glucanases nor the chitinases from numerous fungi or bacterial sources function as antifungal agents, the two activities in combination act synergistically to provide effective control against several plant pathogenic fungi, when the enzymes are applied directly to the plant leaf surface (N. Ogasawara \& H. Tanaka, Japanese Kokoku patent Sho 53-41025, August 1978).

Our laboratory is interested in determining the feasibility of engineering the genes encoding 1,3- $\beta$ glucanase and chitinase into plants to confer resistance to plant-pathogenic fungi. We recently described the cloning and expression in $E$. coli of a gene encoding a Serratia marcescens chitinase (Fuchs et al., 1986). Large quantities of the highly purified $57 \mathrm{kDa}$ chitinase encoded by this gene were produced. Studies with $1,3-\beta$ glucanase have been hampered by the limited quantities of protein available for testing antifungal activity. To address this problem, we sought to isolate genes encoding 1,3- $\beta$-glucanase from Bacillus circulans.

The presence of $1,3-\beta$-glucanases has been well documented in a variety of fungi and bacteria (Doi et al., 1973; Manners \& Wilson, 1973; Martin et al., 1980; Tanaka \& Phaff, 1965; Usui et al., 1985). B. circulans WL-12 was selected as the source of the genes encoding $1,3-\beta$-glucanase for these studies for the following 
reasons: (1) 1,3- $\beta$-glucanases from $B$. circulans have exhibited hydrolysis of fungal cell walls (Horikoshi \& Atsukawa, 1973; Kobayashi et al., 1974b); (2) 1,3- $\beta$ glucanases from $B$. circulans have been biochemically well characterized (Esteban et al., 1984; Kobayashi et al., 1974a; Rombouts \& Phaff, 1976; Tanaka \& Phaff, 1965); and (3) the gene(s) encoding $1,3-\beta$-glucanase(s) from Bacillus species are likely to be expressed in $E$. coli (Borriss et al., 1985; Cantwell \& McConnell, 1983). The molecular cloning and expression in $E$. coli of $1,3 / 1,4-\beta$ glucanases from both $B$. subtilis (Cantwell \& McConnell, 1983; Robson \& Chambliss, 1986) and B. amyloliquefaciens (Borriss et al., 1985) have been described.

Many micro-organisms, including $B$. circulans, which exhibit $1,3-\beta$-glucanase activity, produce multiple enzyme species (Doi et al., 1973; Kobayashi et al., $1974 a$; Sietsma \& Wessels, 1979; Skujins et al., 1965; Usui et al., 1985; Yamamoto et al., 1983). The isolation of clones which produce unique 1,3- $\beta$-glucanases would enable both the circumvention of the problems associated with purifying individual $1,3-\beta$-glucanases from a complex mixture of similar activities and the opportunity to introduce these genes directly into plants for in vivo analysis of their efficacies. This paper describes the cloning and expression of the genes encoding two independent 1,3- $\beta$-glucanases from $B$. circulans WL-12, and the subsequent purification and characterization of each activity.

\section{Methods}

Bacterial strains and culture conditions. B. circulans WL-12 was kindly provided by $H$. J. Phaff through the culture collection of the Department of Food Science and Technology, University of California, Davis, CA, USA. $B$. circulans was grown at $30^{\circ} \mathrm{C}$ under constant aeration in medium containing $0.7 \%$ Difco yeast nitrogen base, $0.1 \mathrm{M}$ sodium phosphate ( $\mathrm{pH} 6.8$ ), and either $0.25 \%$ yeast cell walls or $0.75 \%$ pachyman with or without $0.05 \%$ glucose.

E. coli SR 193 [C600 rspL hsdR Leu- Pro- supE ( $\lambda$ cI857 Bam58-71 plac5)] was obtained from S. Rogers (Monsanto Co., St Louis, MO, USA) and routinely grown at $30^{\circ} \mathrm{C}$ to stationary phase in Luria broth (LB) medium (Miller, 1972). Tetracycline $\left(12.5 \mu \mathrm{g} \mathrm{ml}^{-1}\right.$ ) was added for plasmid-containing strains. Plasmid pRmSL26, from which pLAFR1 was derived by EcoRI digestion and ligation, was provided by F. M. Ausubel, Harvard University, Boston, MA, USA.

$1,3-\beta$-Glucanase-positive clones were identified by screening tetracycline-resistant, cosmid-containing strains on aniline blue-pachyman plates (Mahasneh \& Stewart, 1980). Colonies producing active 1,3- $\beta$ glucanase developed clear zones on a blue background on this medium due to natural cell lysis and release of intracellular enzyme activity.

Enzyme assay. 1,3- $\beta$-Glucanase activity was determined by measuring the reducing power released from the substrate, laminarin, using a modification of the method described by Somogyi (1952). A typical reaction mixture $(500 \mu \mathrm{l})$ containing $0.1 \mathrm{M}$-citrate/phosphate buffer (pH 6.5), laminarin $\left(1 \mathrm{mg} \mathrm{ml}^{-1}\right)$ and enzyme was incubated at $37^{\circ} \mathrm{C}$ for $15 \mathrm{~min}$. Specific activities are expressed as $\mu \mathrm{mol}$ reducing sugar (glucose) formed $\min ^{-1}$ (mg protein) $)^{-1}$. Lytic activity was determined by the addition of an appropriate amount of 1,3- $\beta$-glucanase to a dilution of a Saccharomyces cerevisiae cell wall suspension in $0 \cdot 1 \mathrm{M}$ citrate/phosphate buffer ( $\mathrm{pH} 6.5$ ) to give a final $\mathrm{OD}_{550}$ of 1.2 in a final volume of $1.0 \mathrm{ml}$. The decrease in $\mathrm{OD}_{550}$ was monitored over time in reaction mixtures shaken at 100 r.p.m. at $37^{\circ} \mathrm{C}$. Protein concentrations were determined by the method of Bradford (1976), with bovine serum albumin as a standard.

Preparation of yeast cell walls. Cell walls from $S$. cerevisiae were prepared essentially as described by Okagbue \& Lewis (1985).

Crude enzyme preparation. B. circulans WL-12 culture supernatants were separated from bacterial cells by centrifugation at $20000 \mathrm{~g}$ for $20 \mathrm{~min}$ and were concentrated in a stirred cell using Amicon YM-10 membranes. The concentrated material was dialysed extensively against assay buffer and stored at $-80^{\circ} \mathrm{C}$.

Cells of E. coli SR 193 and derivatives containing recombinant cosmid clones were suspended in either $50 \mathrm{~mm}$-potassium phosphate buffer $(\mathrm{pH} \mathrm{7.2)}$ or $20 \mathrm{mM}$-ethanolamine ( $\mathrm{pH} \mathrm{9.0)}$ as indicated in the text. The suspension was disrupted by sonication followed by centrifugation. The extract was then passed through a Sephadex G-25 column, equilibrated in starting buffer, to remove small molecules which might interfere with enzyme assays.

Construction and screening of a B. circulans cosmid library. A cosmid library of $\boldsymbol{B}$. circulans WL-12 chromosomal DNA was prepared in pLAFR1 as described by Maniatis et al. (1982). B. circulans chromosomal DNA was isolated as described by Barry (1986). Cosmid pLAFR1 was isolated by a modification of the procedure of Birnboim \& Doly (1979) and purified on NACS-52 resin following the manufacturer's instructions (Bethesda Research Laboratories). EcoRIcleaved pLAFR 1 and $B$. circulans DNA were ligated, packaged into $\lambda$ heads in vitro, and used to infect $E$. coli SR 193 cells as described by Maniatis et al. (1982).

Approximately 1100 tetracycline-resistant colonies were screened for $1,3-\beta$-glucanase activity on aniline blue-pachyman plates at $30^{\circ} \mathrm{C}$. Two independent clones were identified which expressed $1,3-\beta$-glucanase activity in $E$. coli. The plasmids in these clones were designated pMON5401 (27.0 kb of cloned DNA) and pMON5402 (24.7 kb of cloned DNA).

Purification of 1,3- $\beta$-glucanase from E. coli SR193(pMON5401). The crude extract protein $(3.2 \mathrm{~g})$ obtained from $E$. coli SR 193 containing pMON5401 was desalted as described above and applied to a DEAESepharose column $(5 \times 35 \mathrm{~cm})$ equilibrated with $50 \mathrm{~mm}$-potassium phosphate ( $\mathrm{pH} 7 \cdot 2)$. The column was washed with three bed volumes of starting buffer. 1,3- $\beta$-Glucanase activity was eluted with a 7.0 litre linear gradient of $\mathrm{NaCl}(0-500 \mathrm{~mm})$. Fractions containing $1,3-\beta$ glucanase activity, which eluted at approximately $200 \mathrm{~mm}-\mathrm{NaCl}$, were pooled and concentrated in a stirred cell using an Amicron YM-10 membrane. The partially purified concentrate $(5 \mathrm{ml})$ was dialysed against 5 litres of $10 \mathrm{~mm}$-sodium phosphate buffer $(\mathrm{pH} \mathrm{7.0)}$ and applied to a hydroxylapatite column $(2.5 \times 25 \mathrm{~cm})$ equilibrated with the same buffer. The column was washed with three bed volumes of starting buffer and eluted with a 1.4 litre linear $(10-500 \mathrm{~mm})$ sodium phosphate gradient. Fractions containing 1,3- $\beta$-glucanase activity eluted at $50-$ $100 \mathrm{~mm}$-sodium phosphate and were pooled, concentrated, and loaded onto an Ultrogel AcA44 column $(116 \times 90 \mathrm{~cm})$ equilibrated in $50 \mathrm{~mm}$ potassium phosphate buffer ( $\mathrm{pH} 6.8$ ). The $1,3-\beta$-glucanase-containing fractions were pooled, concentrated, and stored at $-20^{\circ} \mathrm{C}$. All the chromatographic steps were carried out at $4{ }^{\circ} \mathrm{C}$.

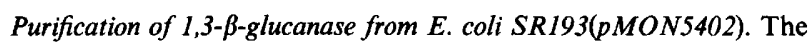
crude protein extract $(1.8 \mathrm{~g})$ derived from $E$. coli SR193 containing pMON5402 was desalted as described above and applied to a DEAESepharose column $(5 \times 30 \mathrm{~cm})$ equilibrated with $20 \mathrm{~mm}$-ethanolamine 
(pH 9.0). The column was washed with three bed volumes of starting buffer and 1,3- $\beta$-glucanase was eluted with a 6.0 litre linear $\mathrm{NaCl}$ gradient $(0-125 \mathrm{mM})$. Fractions containing $1,3-\beta$-glucanase activity, which eluted at approximately $30 \mathrm{mM}-\mathrm{NaCl}$, were pooled, concentrated to $5 \mathrm{ml}$ and dialysed against 5 litres of $10 \mathrm{~mm}$-sodium phosphate buffer (pH 7.0). The dialysate was loaded onto a hydroxylapatite column $(1.5 \times 20 \mathrm{~cm})$ equilibrated in the above buffer. The column was washed with three bed volumes of starting buffer and 1,3- $\beta$-glucanase activity was eluted with a $300 \mathrm{ml}$ linear (10-300 mM) sodium phosphate gradient. 1,3- $\beta$-Glucanase-containing fractions eluted at approximately $100 \mathrm{~mm}$-sodium phosphate and were pooled, concentrated, and stored at $-20^{\circ} \mathrm{C}$. All fractionation steps were carried out at $4{ }^{\circ} \mathrm{C}$.

Gel electrophoresis. SDS-PAGE analysis was carried out with $12.5 \%$ $(w / v)$ acrylamide slab gels by the procedure of Laemmli (1970). Gels were stained for protein using the silver-staining procedure described by Wray et al. (1981).

Molecular mass determinations. Subunit molecular masses were estimated by SDS-PAGE analysis using bovine serum albumin (66 kDa), ovalbumin (45 kDa), glyceraldehyde-3-phosphate dehydrogenase $(36 \mathrm{kDa})$ and trypsinogen $(24 \mathrm{kDa})$ as standards. Molecular masses of native enzymes were estimated by gel filtration on a Superose-12 FPLC column equilibrated in $100 \mathrm{~mm}$-potassium phosphate buffer ( $\mathrm{pH} 6.8)$; bovine serum albumin $(66 \mathrm{kDa})$, ovalbumin $(45 \mathrm{kDa})$, chymotrypsinogen $(25 \mathrm{kDa})$ and ribonuclease $\mathrm{A}(13 \mathrm{kDa})$ were used as standards.

Isoelectric focusing (IEF). This was performed using an LKB 2117 Multiphor horizontal electrophoresis system with a final acrylamide concentration of $4.8 \%$ and a pH gradient of 3.5-9.5. Running conditions consisted of constant power at $25 \mathrm{~W}$, a maximum voltage of $1200 \mathrm{~V}$, and a running temperature of $4^{\circ} \mathrm{C}$.

Amino acid sequencing. N-terminal amino acid sequencing was performed using automated Edman degradation chemistry on a gasphase sequencer (Applied Biosystems model 470A) as described by Hewick et al. (1981).

Immunological analysis. Antibodies were prepared in rabbits using purified $68 \mathrm{kDa} 1,3-\beta$-glucanase prepared from $E$. coli SR193(pMON5401). Western analyses were performed using the alkaline-phosphatase-conjugated antibody procedure described in the Promega catalogue

Materials. Protein standards for molecular mass determinations were obtained from Pharmacia. Pachyman was purchased from United States Biochemical Corp. Aniline blue, tetracycline, ampicillin, laminarin, $S$. cerevisiae cells, Sephadex G-25 and DEAE-Sepharose were obtained from Sigma. Hydroxylapatite and electrophoresis reagents were purchased from Bio-Rad. Ultrogel AcA44 and ampholytes were obtained from LKB. Restriction enzymes and DNA ligase were purchased from New England BioLabs and used as recommended by the manufacturers.

\section{Results}

Cloning of two 1,3- $\beta$-glucanase genes from B. circulans $W L-12$

Approximately 1100 tetracycline-resistant pLAFR 1 cosmid $E$. coli clones containing $E c o$ RI fragments from partially digested $B$. circulans DNA were screened for $1,3-\beta$-glucanase activity on aniline blue-pachyman plates
Table 1. 1,3- $\beta$-Glucanase activity in crude extract preparations

\begin{tabular}{llcc}
\hline \hline \multicolumn{1}{c}{ Strain } & Plasmid & $\begin{array}{c}\text { Sp. act. } \\
{[\mu \text { mol min }}\end{array}$ & \\
$\left.(\text { mg protein })^{-1}\right]$ & $\begin{array}{c}\text { Lytic } \\
\text { activity* }\end{array}$ \\
\hline B. circulans WL-12 & None & 0.48 & 1.0 \\
E. coli SR193 & None & 0.01 & 0.01 \\
& pMON5401 & 0.14 & 0.9 \\
& pMON5402 & 0.24 & 1.2 \\
\hline \hline
\end{tabular}

* Lytic activity is expressed as the capacity to degrade yeast cell walls (as measured by the decrease in $\mathrm{OD}_{550}$ ) relative to a crude extracellular enzyme preparation from $B$. circulans, which is designated $1 \cdot 0$.

at $30^{\circ} \mathrm{C}$. Three colonies exhibited zones of clearing, due to natural cell lysis, which indicated that a $B$. circulans 1,3- $\beta$-glucanase gene(s) was expressed in $E$. coli. Cosmid DNA was isolated from each of the three $1,3-\beta$ glucanase-positive recombinants. EcoRI restriction analysis revealed that one of the clones contained EcoRI fragments totalling approximately $27.0 \mathrm{~kb}$, whereas the other two clones contained a similar set of EcoRI fragments totalling about $24.7 \mathrm{~kb}$. Unique restriction patterns were generated for each of these two classes of clones when digested with five other restriction enzymes (data not shown). No fragments common to both were identified.

The recombinant strains were also examined for their ability to hydrolyse purified yeast cell walls. E. coli SR 193 containing pMON5401 or pMON5402 was streaked onto an agar medium containing suspended yeast cell walls. Clear zones developed around the colonies of $E$. coli containing either plasmid, indicating that the enzyme(s) produced by each clone does exhibit cell-wall lytic activity (data not shown).

\section{1,3- $\beta$-Glucanase activity in crude enzyme preparations}

Direct enzymic assay of $1,3-\beta$-glucanase in crude enzyme preparations confirmed that 1,3- $\beta$-glucanase was expressed in $E$. coli SR193 containing pMON5401 or pMON5402 (Table 1). 1,3- $\beta$-Glucanase produced from both clones also lysed $S$. cerevisiae cell walls in an in vitro assay, with lytic activities similar to the crude mixture of 1,3- $\beta$-glucanases released into the medium by $B$. circulans (Table 1).

\section{Purification of 1,3- $\beta$-glucanase from E. coli SR 193 (pMON5401) and (pMON5402)}

Crude extract protein from $E$. coli SR193(pMON5401) was passed over a Sephadex G-25 column followed by 


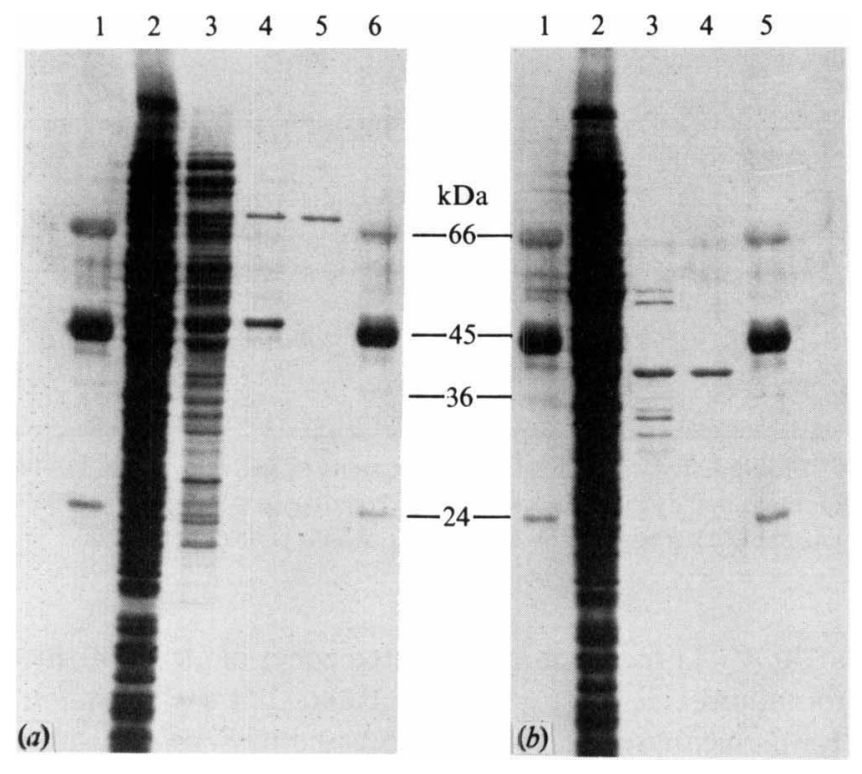

Fig. 1. SDS-PAGE analysis of purified 1,3- $\beta$-glucanases. (a) 1,3- $\beta$ Glucanase from $E$. coli SR 193(pMON5401). Lanes 1 and 6, molecular mass markers; lane 2, crude extract; lane 3, DEAE-Sepharosepurified enzyme; lane 4 , hydroxylapatite-purified enzyme; lane 5 , Ultrogel-AcA44-purified enzyme. (b) 1,3- $\beta$-Glucanase from SR 193(pMON5402). Lanes 1 and 5, molecular mass markers; lane 2, crude extract; lane 3, DEAE-Sepharose-purified enzyme; lane 4, hydroxylapatite-purified enzyme.

chromatography on DEAE-Sephadex, hydroxylapatite and Ultrogel AcA44. 1,3- $\beta$-Glucanase purified in this manner gave a single band on SDS-PAGE, corresponding to a subunit molecular mass of approximately $68 \mathrm{kDa}$ (Fig. 1a). A summary of the purification (Table 2a) shows that 1,3- $\beta$-glucanase from $E$. coli SR193(pMON5402) was purified 200 -fold with a $21 \%$ recovery.

Crude extract protein from E. coli SR193(pMON5402) was passed over a Sephadex G-25 column followed by chromatography on DEAE-Sepharose and hydroxylapatite. SDS-PAGE analysis of the preparation following hydroxylapatite chromatography showed a single protein band with a subunit molecular mass of approximately $40 \mathrm{kDa}$ (Fig. 1 b). A summary of the steps involved in the purification of 1,3- $\beta$-glucanase from $E$. coli SR193(pMON5402) is shown in Table 2(b). The enzyme was purified 68 -fold with an overall recovery of $19 \%$.

\section{Properties of the purified 1,3- $\beta$-glucanases}

Various biochemical and physical properties of the cloned 1,3- $\beta$-glucanases were examined in order to substantiate that the proteins produced from pMON5401 and pMON5402 are distinct and to facilitate comparison of these activities (Table 3) with the

\section{5 \\ 10 \\ 15 \\ $68 \mathrm{kDa} \quad X \times P E V T S M E Y F C P A D$}

\section{$40 \mathrm{kDa} \quad$ A T N W L L W D E F G S}

Fig. 2. Identification of the $\mathrm{N}$-terminal amino acids of the $68 \mathrm{kDa}$ and $40 \mathrm{kDa} 1,3-\beta$-glucanases. $X$ denotes undefined residues.

activities of the 1,3- $\beta$-glucanases described previously. $E$. coli SR193(pMON5401) and (pMON5402) produced 1,3$\beta$-glucanases with subunit molecular masses of 68 and $40 \mathrm{kDa}$, respectively. The molecular masses of the native proteins, estimated using a Superose-12 FPLC gel filtration column, were 45 and $15 \mathrm{kDa}$ for the enzymes from the pMON5401- and pMON5402-containing strains, respectively. The $1,3-\beta$-glucanase from $E$. coli SR193(pMON5401) exhibited a nearly tenfold lower $K_{\mathrm{m}}$ for laminarin than did the enzyme isolated from the pMON5402-containing strain. The optimum $\mathrm{pH}$ for each enzyme was similar, in the range $6 \cdot 0-6 \cdot 5$. The isoelectric points, as determined by IEF gels, were 4.6 and 6.5 for the enzymes from strains containing pMON5401 and pMON5402, respectively. The cell-wall lytic activities of the purified enzymes (Table 3 ) were similar to those of the crude $B$. circulans preparation and the crude extracts of the two constructs (Table 1).

The $68 \mathrm{kDa}$ and $40 \mathrm{kDa}$ purified 1,3- $\beta$-glucanases were subjected to $\mathrm{N}$-terminal sequence analysis and the sequence of the first 15 residues compared (Fig. 2). No homology was observed at the $\mathrm{N}$-terminus, suggesting that the two 1,3- $\beta$-glucanase proteins are independent gene products.

Rabbit polyclonal antibodies were raised against the $68 \mathrm{kDa} \quad 1,3-\beta$-glucanase purified from $E$. coli SR193(pMON5401). Western analysis (Fig. 3) showed that these antibodies reacted specifically with the purified $68 \mathrm{kDa} 1,3-\beta$-glucanase and also with a $68 \mathrm{kDa}$ protein in the crude culture filtrate of $B$. circulans WL- 12 . No cross-reactivity was observed either with the purified $40 \mathrm{kDa} 1,3-\beta$-glucanase or with any other protein in the $B$. circulans crude culture filtrate. This further suggests that the two cloned 1,3- $\beta$-glucanases are derived from two distinct genes.

\section{Discussion}

It has been reported that $B$. circulans WL-12, depending on the growth substrate used as inducer, is capable of producing up to six different 1,3- $\beta$-glucanases (Esteban et al., 1984; Kobayashi et al., 1974a, b; Rombouts \& Phaff, 1976; Tanaka et al., 1978, 1981). Tanaka et al. (1978) proposed that the observed induction patterns are a reflection of the structures of the mixed-linkage glucans 
Table 2. Purification of 1,3- $\beta$-glucanases from E. coli SR193(pMON5401) and (pMON5402)

\begin{tabular}{|c|c|c|c|c|c|}
\hline Step & $\begin{array}{l}\text { Protein } \\
\text { (mg) }\end{array}$ & $\begin{array}{c}\text { Total } \\
\text { activity } \\
\left(\mu \mathrm{mol} \mathrm{min}^{-1}\right)\end{array}$ & $\begin{array}{c}\text { Sp. act. } \\
{\left[\mu \mathrm{mol} \mathrm{min}^{-1}\right.} \\
\left.(\mathrm{mg} \text { protein })^{-1}\right]\end{array}$ & $\begin{array}{c}\text { Recovery } \\
(\%)\end{array}$ & $\begin{array}{l}\text { Purification } \\
\text { (-fold })\end{array}$ \\
\hline \multicolumn{6}{|c|}{ (a) E. coli SR193(pMON5401) } \\
\hline Crude extract & 3321 & 462 & 0.14 & 100 & 1 \\
\hline DEAE-Sepharose & 425 & 398 & 0.94 & 87 & 7 \\
\hline Hydroxylapatite & 14 & 181 & 12.93 & 38 & 92 \\
\hline Ultrogel AcA44 & $3 \cdot 5$ & 98 & $28 \cdot 00$ & 21 & 200 \\
\hline \multicolumn{6}{|c|}{ (b) E. coli SR193(pMON5402) } \\
\hline Crude extract & 1828 & 432 & 0.24 & 100 & 1 \\
\hline DEAE-Sepharose & 21 & 159 & 7.57 & 37 & 32 \\
\hline Hydroxylapatite & 5 & 81 & $16 \cdot 20$ & 19 & 68 \\
\hline
\end{tabular}

Table 3. Properties of purified 1,3- $\beta$-glucanases

\begin{tabular}{lcc}
\hline \hline & \multicolumn{2}{c}{ Enzyme purified from } \\
& \multicolumn{2}{c}{ E. coli SR193 containing: } \\
\cline { 2 - 3 } \multicolumn{1}{c}{ Property } & pMON5401 & pMON5402 \\
\hline Mol. mass (kDa) & & \\
SDS-PAGE & 68 & 40 \\
Superose-12 & 45 & 15 \\
$\left.K_{\mathrm{m} \text { app. (mg ml }}{ }^{-1}\right)^{*}$ & 1.25 & 0.143 \\
pH optimum & $6.0-6.5$ & $6 \cdot 0-6 \cdot 5$ \\
pI & 4.6 & 6.5 \\
Lytic activity $\dagger$ & $1 \cdot 20$ & 0.88 \\
\hline \hline
\end{tabular}

* The $K_{\mathrm{m}}$ data correspond to values obtained from a LineweaverBurk plot using laminarin as the substrate.

† Lytic activity is expressed as described in Table 1.

used as growth substrates, and that several enzyme species are likely to act synergistically. To determine whether individual or multiple $1,3-\beta$-glucanases, in combination with chitinase(s), function as antifungal agents, individually purified 1,3- $\beta$-glucanases are required.

Two DNA fragments, each containing a unique gene encoding a $1,3-\beta$-glucanase, were isolated from a cosmid library of $B$. circulans WL-12 DNA by screening 1100 tetracycline-resistant pLAFR 1 cosmid clones. Expression of the 1,3- $\beta$-glucanase genes in $E$. coli was demonstrated by (1) zones of clearing on aniline bluepachyman plates; (2) zones of clearing on agar plates containing yeast cell walls; (3) direct assay of enzyme activity in crude and purified preparations; and (4) assay of cell-wall lytic activity in both crude and purified preparations using suspensions of purified yeast cell walls. These two genes and their protein products were shown to be distinct based on both genetic and biochemical evidence. Restriction enzyme patterns generated with six restriction enzymes showed that the two cosmids contained no common fragments. The proteins produced from the two clones differed substantially in size (40 and $68 \mathrm{kDa})$. Their $\mathrm{N}$-terminal amino acid sequences, determined through fifteen places, showed no homology. Polyclonal antibodies generated against the $68 \mathrm{kDa}$ protein purified from $E$. coli SR193(pMON5401) cross-reacted with the $68 \mathrm{kDa}$ protein purified from SR193(pMON5401) and $B$. circulans crude culture filtrate, but not with the $40 \mathrm{kDa}$ protein purified from SR193(pMON5402). Finally, the purified $40 \mathrm{kDa} 1,3-\beta$-glucanase from pMON5402 had a tenfold lower apparent $K_{\mathrm{m}}$ for laminarin than the $68 \mathrm{kDa} 1,3-\beta$ glucanase from pMON 5401 . These data strongly support the unique identity of the cloned genes in plasmids pMON5401 and pMON5402.

The biochemical characteristics listed in Table 3 suggest that the two $B$. circulans $1,3-\beta$-glucanases may correspond to previously reported $1,3-\beta$-glucanases. The 1,3- $\beta$-glucanase produced by $E$. coli SR193(pMON5401) possesses lytic activity towards yeast cell walls, has a $K_{\mathrm{m}}$ for laminarin of $1.25 \mathrm{mg} \mathrm{ml}^{-1}$ and exhibits a $\mathrm{pI}$ of 4.6 (Table 3). Esteban et al. (1984) described the isolation of a lytic enzyme, $1,3-\beta$-glucanase IV, with very similar properties. They reported an enzyme with a $K_{\mathrm{m}}$ of $1.23 \mathrm{mg} \mathrm{ml}^{-1}$ for laminarin, and an identical pI of 4.6 . The molecular masses estimated for the native proteins differ considerably: $68 \mathrm{kDa}$ for the enzyme described in this report versus $21 \mathrm{kDa}$ for that described by Esteban $e t$ al. (1984). However, as discussed below, this difference in molecular mass may not be accurate. The 1,3- $\beta$ glucanase isolated from $E$. coli SR193(pMON5402) proved to be similar to $1,3-\beta$-glucanase I described by Rombouts \& Phaff (1976). They purified a cell-wall lytic enzyme with a subunit molecular mass of $40 \mathrm{kDa}$, a $K_{\mathrm{m}}$ for laminarin of $0.143 \mathrm{mg} \mathrm{ml}^{-1}$, and a $\mathrm{pH}$ optimum of 


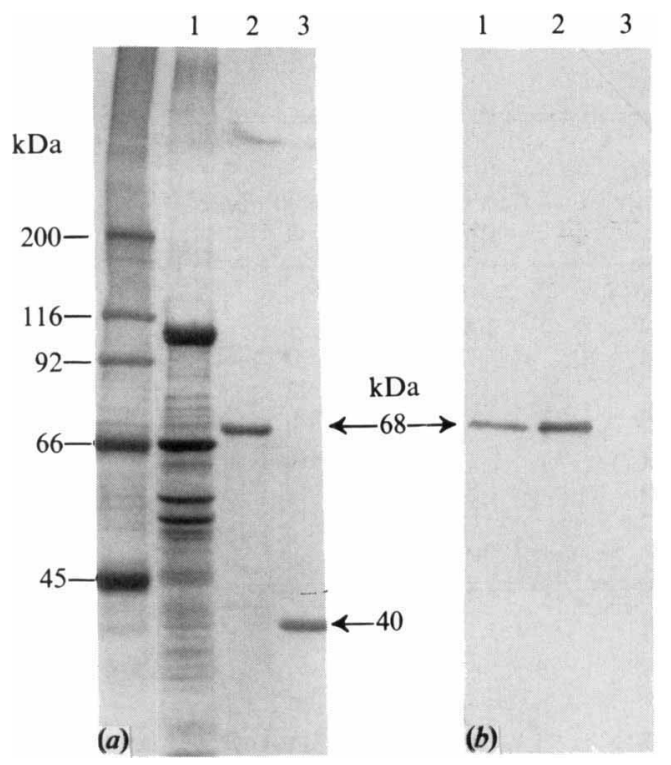

Fig. 3. SDS-PAGE analysis of 1,3- $\beta$-glucanases and Western blot hybridization with rabbit polyclonal antibodies raised against the $68 \mathrm{kDa}$ glucanae. (a) SDS-PAGE. First lane, molecular mass markers; lane 1 , crude culture filtrate from $B$. circulans WL-12; lane 2, purified $68 \mathrm{kDa} 1,3-\beta$-glucanase; lane 3 , purified $40 \mathrm{kDa} 1,3-\beta$-glucanase. (b) Western blot. Lanes 1-3 correspond to lanes 1-3 in $(a)$.

5.5. The enzyme purified from $E$. coli SR193(pMON5402) also lyses yeast cell walls, has an identical subunit molecular mass of $40 \mathrm{kDa}$, and a similar $K_{\mathrm{m}}$ of $0.105 \mathrm{mg} \mathrm{ml}^{-1}$, but gives a slightly different $\mathrm{pH}$ optimum of $6 \cdot 0-6.5$ (Table 3 ). It is of interest that the molecular mass values obtained for both cloned 1,3- $\beta$ glucanases were consistently lower when using gel filtration chromatography as opposed to SDS-PAGE analysis. The reason for this observation is unclear. However, it is possible that $1,3-\beta$-glucanases exhibit a slight affinity for the agarose-based medium used in manufacturing Pharmacia Superose columns, which lowers the apparent molecular mass. Usui et al. (1985) observed the same phenomenon in the purification and molecular mass estimation of $1,3-\beta$-glucanases isolated from Rhizoctonia solani. The $21 \mathrm{kDa}$ molecular mass reported by Esteban et al. (1984) for their 1,3- $\beta$-glucanase IV was determined by molecular sieve chromatography and hence may also be an underestimation.

The cloning and expression of genes coding for hydrolytic enzymes which are capable of degrading fungal cell wall components is the first step to the engineering of plants with these activities. With both a chitinase gene from $S$. marcescens and two 1,3- $\beta$ glucanase genes from $B$. circulans WL-12 cloned, it will now be possible to test both the in vitro effects of the purified enzymes and to insert these genes into plants to evaluate their in planta efficacy against plant-pathogenic fungi.

We thank Bruce Bishop, Ned Siegel, Bob Heeren, David Drahos and Sylvia McPherson for their technical support and suggestions throughout the course of these studies. We also thank Ganish Kishore, Sue MacIntosh and Alan Berry, for critical review of this manuscript and Lori VanDelinder and Dee Rollo for typing this manuscript.

\section{References}

Abel, P. P., Nelson, R. S., Hoffman, B. De N., Rogers, S. G., Fraley, R. T. \& BeACHY, R. N. (1986). Delay of disease development in transgenic plants that express the tobacco mosaic virus coat protein gene. Science 232, 738-743.

Barry, G. F. (1986). Permanent insertion of foreign genes into the chromosomes of soil bacteria. Bio/Technology 4, 446-449.

Barton, K. A., Whiteley, H. R. \& Young, N. S. (1987). Bacillus thiringiensis $\delta$-endotoxin expressed in transgenic Nicotiana tabacum provides resistance to lepidopteran insects. Plant Physiology 85, $1103-1109$.

BeLl, A. A. (1981). Biochemical mechanisms of disease resistance. Annual Review of Plant Physiology 321, 21-81.

BiRnboim, H. C. \& Doly, J. (1979). A rapid alkaline extraction procedure for screening recombinant plasmid DNA. Nucleic Acids Research 7, 1513-1524.

BRADFORD, M. M. (1976). A rapid and sensitive method for the quantitation of microgram quantities of protein utilizing the principle of protein dye binding. Analytical Biochemistry 72, 248-254.

BorRis, R., Baumlein, H. \& Hofemeister, J. (1985). Expression in Escherichia coli of a cloned $\beta$-glucanase gene from Bacillus amyloliquefaciens. Applied Microbiology and Biotechnology 22, 63-71.

CANTwell, B. A. \& MCConnell, D. J. (1983). Molecular cloning and expression of a Bacillus subtilis $\beta$-glucanase gene in Escherichia coli. Gene 23, 211-219.

Chesters, C. G. C. \& Bull, A. T. (1963). The enzymatic degradation of laminarin. 1. The distribution of laminarinase among microorganisms. Biochemical Journal 86, 28-31.

De Block, M., Botterman, J., Vandewiele, M., DockX, J., Thoen, C., Gossele, V., Movva, N. R., Thompson, C., Van Montagu, M. \& LeEMANS, J. (1987). Engineering herbicide resistance in plants by expression of a detoxifying enzyme. EMBO Journal 6, 2513-2518.

DoI, K., DoI, A. \& FuKUI, T. (1973). Purification and properties of lytic $\beta$-glucanase from an Arthrobacter bacterium. Agricultural and Biological Chemistry 37, 1619-1627.

Esteban, R., Nebrada, A. R. \& Villa, T. G. (1984). Synthesis and regulation of Bacillus circulans WL-12 1,3- $\beta$-D-glucanases. Journal of General Microbiology 130, 2483-2487.

Fischhoff, D. A., Bowdish, K. S., Perlak, F. J., Marrone, P. G., McCormick, S. M., Niedermeyer, J. G., Dean, D. A., KusanoKretzmer, K., Mayer, E. J., Rochester, D. E., Rogers, S. G. \& FRALEY, R. T. (1988). Insect tolerant transgenic tomato plants. Bio/Technology 5, 807-813.

Fuchs, R. L., MCPherson, S. A. \& Drahos, D. J. (1986). Cloning of a Serratia marcescens gene encoding chitinase. Applied and Environmental Microbiology 51, 504-509.

Hewick, R. M., Hunkapiller, M. W., Hood, L. E. \& Dreyer, W. J. (1981). A gas-liquid solid phase peptide and protein sequenator. Journal of Biological Chemistry 256, 7990-7997.

HoRIKoshi, K. \& AtsuKaWA, Y. (1973). $\beta$-1,3-Glucanase produced by alkalophilic bacteria Bacillus no. K-12-5. Agricultural and Biological Chemistry 37, 1449-1456.

Kobayashi, T., Tanaka, H. \& Ogasawara, N. (1974a). Concerted inductions of multiple $\beta-1,3$ glucanases in Bacillus circulans WL-1 2 in response to three different substrates. Agricultural and Biological Chemistry 38, 967-972.

Kobayashi, Y., TanaKa, H. \& Ogasawara, N. (1974b). Multiple $\beta-1,3$ glucanases in the lytic enzyme complex of Bacillus circulans WL-12. Agricultural and Biological Chemistry 38, 959-965. 
Kobayashi, Y., Tanaka, H. \& Ogasawara, N. (1974c). Purification and properties of $\mathrm{F}-1 \mathrm{a}, \mathrm{a} \beta-1,3$ glucanase which is highly lytic toward cell walls of Piricularia oryzae P2. Agricultural and Biological Chemistry 38, 973-978.

LAEMMLI, U. K. (1970). Cleavage of structural proteins during the assembly of the head of bacteriophage T4. Nature, London 227, 680685.

Mahasneh, A. M. \& STewart, D. J. (1980). A medium for detecting $\beta$ 1,3 glucanase activity in bacteria. Journal of Applied Bacteriology $\mathbf{4 8}$, 457-458.

Maniatis, T., Fritsch, E. F. \& Sambrook, J. (1982). Molecular Cloning, a Laboratory Manual. Cold Spring Harbor, NY: Cold Spring Harbor Laboratory.

MANNERS, D. J. \& Wilson, G. (1973). Studies on $\beta$-glucanases: some properties of a bacterial endo- $\beta(1 \rightarrow 3)$-glucanase system. Biochemical Journal 135, 11-18.

Martin, D. F., Priest, F. G., Todd, C. \& Goodfellow, M. (1980). Distribution of $\beta$-glucanases within the genus Bacillus. Applied and Environmental Microbiology 40, 1136-1138.

Miller, J. H. (1972). Experiments in Molecular Genetics. Cold Spring Harbor, NY: Cold Spring Harbor Laboratory.

Nichols, E. J., BeckmaN, J. M. \& HADWiger, L. A. (1980). Glycosidic enzyme activity in pea tissue and pea-Fusarium solani interactions. Plant Physiology 66, 199-204.

NitzsCHE, W. (1983). Chitinase as a possible resistance factor for higher plants. Theoretical and Applied Genetics 65, 171-172.

OKaGbue, R. N. \& LEWIS, M. J. (1985). Influence of mixed culture conditions on yeast-wall hydrolytic activity of Bacillus circulans WL12 and on extractability of astaxanthin from the yeast Phaffia rhodozyma. Journal of Applied Bacteriology 59, 243-255.

RoBson, L. M. \& Chambliss, G. H. (1986). Cloning of the Bacillus subtilis DLG $\beta$-1,4-glucanase gene and its expression in $E$. coli and $B$. subtilis. Journal of Bacteriology 165, 612-619.

Rombouts, F. M. \& PHAFF, H. J. (1976). Lysis of yeast cell walls: lytic $\beta$-(1,3)-glucanases from Bacillus circulans WL-12. European Journal of Biochemistry 63, 121-130.

Shah, D. M., Horsch, R. B., KleE, H. J., Kishore, G. M., Winter, J. A., Tumer, N. E., Hironaka, C. M., Sanders, P. R., Gasser, C. S., Aykent, S., Siegel, N. R., Rogers, S. G. \& Fraley, R. T.
(1986). Herbicide tolerance in transgenic plants. Science 233, 478481.

Sietsma, J. A. \& Wessels, J. G. H. (1979). Evidence for covalent linkages between chitin and $\beta$-glucan in a fungal wall. Journal of General Microbiology 114, 99-108.

Skujins, J. J., Potgieter, H. J. \& Alexander, M. (1965). Dissolution of fungal cells by a streptomycete chitinase and $\beta-(1 \rightarrow 3)$-glucanase. Archives of Biochemistry and Biophysics 111, 358-364.

SomogYI, M. (1952). Notes on sugar determination. Journal of Biological Chemistry 195, 19-23.

Tanaka, H. \& PhafF, J. H. (1965). Enzymatic hydrolysis of yeast cell walls. I. Isolation of wall-decomposing organisms and separation and purification of lytic enzymes. Journal of Bacteriology 89, 15701580.

TaNaKa, H., ITaKuRA, K. \& TODa, K. (1978). Concerted induction of $\beta$-glucanases of Bacillus circulans WL-12 in response to various yeast glucans. Agricultural and Biological Chemistry 42, 1631-1636.

Tanaka, H., Kobayashi, Y., Itakura, K. \& KamimiYa, S. (1981). Concerted induction of cell wall lytic enzymes in Bacillus circulans WL-12. Advances in Biotechnology 4, 593-598.

Tumer, N. E., O'Connell, K. M., Nelson, R. S., Sanders, P. R., Beachy, R. N., Fraley, R. T. \& Shah, D. M. (1987). Expression of alfalfa mosaic virus coat protein confers cross-protection in transgenic tobacco and tomato plants. EMBO Journal 6, 1181-1188.

Usui, T., Totani, K., Totsuka, A. \& OGUChI, M. (1985). Purification of endo-( $1 \rightarrow 3)-\beta$-D-glucanases lysing yeast cell walls from Rhizoctonia solani. Biochimica et Biophysica Acta 840, 255-263.

VAECK, M., Reynaerts, A., Hofte, H., Kansens, S., De Beuckeleer, M., Dean, C., Zabeau, M., Van Montagu, M. \& Leemans, J. (1987). Transgenic plants protected from insect attack. Nature, London 328, 33-37.

Wray, W., Boulikas, T., Wray, V. P. \& Hancock, R. (1981). Silver staining proteins in polyacrylamide gels. Analytical Biochemistry 118 , 197-203.

Yamamoto, S., MiYaGi, M. \& Nagasaki, S. (1983). Amino acid residues involved in the action of endo- $(1 \rightarrow 3)-\beta$-D-glucanase II from Flavobacterium dormitator var. glucanolyticae FA-5. Carbohydrate Research 114, 137-145. 